УДК 37.012:929(045)

DOI:

Ірина Розман, кандидат педагогічних наук, доцент кафедри англійської філології та методики викладання іноземних мов Мукачівського державного університету

\title{
СТРУКТУРНО-ОСОБИСТІСНІ АСПЕКТИ ВИВЧЕННЯ ПЕДАГОГІЧНОӤ ПЕРСОНАЛІЇ
}

У статті обгрунтовано потребу структурно-особистісного аналізу персоналї, щзо дозволяє узагальнити науковий досвід та спроектувати підхід до послідовного вивчення особистості. Зосереджено увагу на розвиток та становлення психосочіальної структури особистості. Зазначено, щуо вплив на життя та творчий і професійний “портрет” персоналії поповнюється або взаємозамімується певними психічними рисами. Закиентовано увагу на те, щзо в дослідженні педагогічної персоналії необхідно особливу увагу приділити впливу темпераменту на розвиток окремої персоналії. 3 'ясовано, щуо існують мотиви та стимули, які, з одного боку, характеризують спрямованість і ставлення особи до певного предмета, явищза, соціального середовища, з іншого, виступають рушійною силою до навчання, самоосвіти, творчої та інших видів діяльності. Особлива увага зосереджена на послідовності вивчення персоналії, коли дослідник опирається на документальні матеріали та спогади сучасників.

Ключові слова: психолого-педагогічна література; самоаналіз; комплексний підхід; послідовність вивчення; людська особистість.

Jim. 5.

Iryna Rozman, Ph. D.(Pedagogy), Associate Professor of the English Philology and Teaching Methods of Foreign Languages Department Mukachevo State University

\section{STRUCTURALAND PERSONALASPECTS OF STUDY OF PEDAGOGICAL PERSONNEL}

The necessity of the structurally-individual analysis of the personality, which allows to generalize scientific experience and to plan an approach to the consistent study of personality, is substantiated. Focused attention on the development and formation of the psychosocial structure of the individual. It is noted that the impact on life and the creative and professional "portrait" of the person is replenished or interchangeable with certain psychic traits. The emphasis is placed on the fact that in the study of pedagogical personnel it is necessary to pay special attention to the influence of temperament on the development of a separate person. It has been found out that there are motives and incentives that, on the one hand, characterize the orientation and attitude of the person to a certain subject, phenomenon, social environment, on the other hand, are the driving force for learning, self-education, creative and other activities.

It is noted that in exploring the nature of the creative, professional, socio-cultural activities of the people during the following life periods, researchers, mainly focusing on creative achievements, career growth, life 's successes and failures, explain them, as a rule, "external", "objective" factors in the form of exterior ideological influences, struggle for national ideals, etc. Along with the mentioned aspects, when studying the pedagogical personality, the biographer must be aware of the manifestations peculiarities of each age crisis that affects social activity. Given the characteristics of personalities, the biographer has to understand that between types of higher nervous activity, on the one hand, and the nature, creative potential of the individual, on the other one, there is an undoubted and expressive interconnection that needs to be identified and explained, in particular through the prism of its influence on the content and the result of the theoretical searches, professional-educational, scientific-organizational, and other manifestations of social activity.

The use of scientific and theoretical constructs of personology can be particularly productive in the study of the teachers' life in the complex and contradictory periods of the history of Ukraine (the era of Stalin totalitarianism, "thaw", "stagnation", "restructuring", etc.), which were accompanied by losses in human fate, social crises, deformations in the humanities, etc. All these stipulated the consistent psychic conditions in the bearers of Ukrainian pedagogical thought, influenced its progress, spirituality and mentality of the whole Ukrainian community.

Keywords: psychological and pedagogical literature; self-analysis; a complex approach; sequence of studying; human personality.

П остановка проблеми. Розроблена в персонології методологія структурноособистісного аналізу орієнтує вчених на комплексний інтегративний підхід до вивчення педагогічної персоналії, який передбачає врахування як загальної, властивої всім людям, так і її власної унікальної “конструкції”. Доволі продуктивним науково-методологічним інструментом для дослідження педагогічних персоналій $\epsilon$ напрям (аспект) персонології, який охоплює психологічні концепції гуманістичної особистості. Він містить сукупність цінних ідей, теорій, підходів, принципів вивчення особистості, зокрема педагога як історичної персоналії, в її 


\section{СТРУКТУРНО-ОСОБИСТІСНІ АСПЕКТИ ВИВЧЕННЯ ПЕДАГОГІЧНОЇ ПЕРСОНАЛІЇ}

цілісних структурних типологічних і динамічних характеристиках. Саме в персонології дивовижно переплелися проблеми філософії, психології, соціології, біології, етики, природничих і медичних наук, які зі своїх позицій вивчають людську особистість, її психічні і творчі стани. 3 таких позицій необхідно підходити до з'ясування означеного в назві статті питання.

Аналіз наукових досліджень і публікацій. Теоретичну основу дослідження становить доробок українських і зарубіжних учених: 3 методології дослідження педагогіки (І. Аносов, Л. Артамошкін, М. Берулава, Б. Бім-Бад, А. Закірова, І. Зязюн, Н. Іпполітова, М. Каган, В. Краєвський, Г. Кузьменко, В. Кремень, В. Лаппо, В. Луговий, О. Невмержицька, О. Новіков, В. Онищенко, А. Сбруєва, С. Сисоєва, Н. Скотна, Н. Ткачова та ін.), історії педагогіки (О. Адаменко, В. Безрогов, С. Бобришов, М. Богуславський, Л. Ваховський, А. Вихрущ, С. Гончаренко, Н. Дічек, О. Сухомлинська, Є. Хриков та ін.).

Мета дослідження - 3'ясувати структурноособистісні аспекти вивчення педагогічної персоналії.

Для розв'язання поставлених у статті завдань використано загальні й спеціальні методи наукового дослідження: пошуково-бібліографічний, генетичний, проблемно-хронологічний - для вивчення багаторівневої динаміки розвитку творчої і професійної діяльності досліджуваних педагогів, $з$ одного боку, тенденцій розвитку педагогічної персоналії-з іншого.

Виклад основного матеріалу. Узагальнення цього наукового досвіду дозволяє спроектувати підхід, який передбачає послідовне вивчення іiі: а) соціально зумовлених властивостей і якостей (світогляд, спрямованість інтересів, моральні характеристики); б) біологічно зумовлених параметрів (темперамент, задатки, інстинкти і т. ін.); в) специфіки окремих психічних станів (приміром, здатність до запам'ятовування тощо); інтелектуального, навчального, професійного досвіду (знання, уміння, навички, звички). Слід розуміти, що не всі ці риси, властивості однаково значущі для вивчення педагогічної персоналії, однак вони взаємопов'язані й у сукупності відтворюють цілісну особистість. Сутніснозмістові характеристики означених компонентів психосоціальної структури особистості достатньо висвітлені у психолого-педагогічній літературі [3, 87].

При розв'язанні цього дослідницького завдання варто враховувати такі загальні тенденції і принципи.

По-перше, у процесі розвитку особистість віддаляється від “природного джерела” свого походження (атмосфери родини, місця народження тощо), набуваючи соціально зумовлених рис і властивостей, детермінованих суспільними впливами.

По-друге, кожну педагогічну персоналію визначають властиві лише їй специфічні якості. Її індивідуальність (найбільш стабільні, виразні якості) формуються у процесі онтогенезу. Тому впродовж життя творчий і професійний портрет персоналії поповнюється або взаємозаміщується такими психічними рисами, як, приміром, розсіяність, забудькуватість, роздратованість, підвищена вразливість, сентиментальність тощо. Вони можуть бути викликані притаманними творчій особі заглибленням у власні роздуми, нереалізованістю життєвих планів, безліччю інших психогенних чинників.

По-третє, жодна психічна властивість не є вродженою, бо успадковуються лише особливості анатомо-фізіологічної конструкції будови і вищої нервової діяльності, які визначаються задатками, що також видозмінюються в процесі особистісної еволюції. Їхня сукупність становить обдарованість, а здатність до іiі реалізації, удосконалення визначається феноменом таланту як вияву найвищого рівня творчої майстерності.

По-четверте, рушійною силою творчої, професійної, громадської діяльності педагогічної персоналії виступають інтереси, мотиви, стимули, які, 3 одного боку, характеризують і1і спрямованість і ставлення до певного предмета, явища, соціального середовища, 3 іншого, виступають рушійною силою до навчання, самоосвіти, творчої та інших видів діяльності, самовдосконалення в процесі виконання своїх функціональних обов'язків.

Варто зважати, що попри “широту інтересів”, які забезпечують усебічний розвиток інтересів, вони фокусуються на провідному виді діяльності (приміром, пристрасть до науки; удосконалення педагогічної майстерності; розвиток національної освіти тощо) і допомагають розв'язувати відповідні завдання. Окрему увагу в дослідженні педагогічної персоналії доцільно приділити темпераменту (лат. - суміш, певні співвідношення частин), що як біологічний тип реакцій $є$ вродженою і досить статичною особливістю, тож істотно зумовлює і позначає притаманні особі специфічні якості.

Ця проблема достатньо висвітлена у психолого-педагогічній літературі [5, 483 - 488], тому лише відзначмо, що, працюючи у вказаному напрямі, науковець не повинен обмежуватися визначенням притаманного особі одного з типів темпераменту (згідно з класичними системами 


\section{СТРУКТУРНО-ОСОБИСТІСНІ АСПЕКТИ ВИВЧЕННЯ ПЕДАГОГІЧНОЇ ПЕРСОНАЛЇ}

I. Канта, І. Павлова - сангвінічний, меланхолічний, холеричний, флегматичний). Він має показати, як комбінації їхніх властивостей (врівноваженість, вразливість, збудженість, рішучість, рухливість, інертність, нестримність тощо) позначалися на вчинках, вибору шляхів досягнення завдань, кар'єрному зростанні, інших аспектах суспільної діяльності.

До вивчення характеру (грец. - риса, особливість) педагогічної персоналії, що розкриває іiї в усьому розмаїтті діяльнісних виявів, доцільно підходити, зважаючи на сукупність стрижневих психічних властивостей, які проявляються в їі поведінці та ставленні до “іншого”, свого “Я”, суспільства загалом. Вони виставляються як базові, часто опозиційні "маркери": чесність - брехливість, колективізм - індивідуалізм, альтруїзм - егоїзм, працелюбство - лінивство і т. ін.

Важливо не обмежуватися констатацією певної риси характеру (який, на відміну від темпераменту, визначає соціальну, а не біологічну сутність людини), а розглядати його як один 3 елементів цілісної психосоціальної сутності особи та крізь призму її суспільної діяльності, місця в соціумі.

Системний підхід до цієї проблеми забезпечує вибір наукової типології, класифікації, що відповідають дослідницьким завданням. Зокрема, доволі продуктивною для вивчення педагогічної персоналії може бути розроблена англійським психологом Г. Айзенком типологія особистості, яка за таким критерієм, як домінуючий психотип, розкриває творчий потенціал особистості: налаштованим на внутрішній світ інтровертам властиве аналітичне, мозаїчне сприйняття дійсності, екстравертам синтетичне, цілісне, а проміжними між цими амбівалентам - ті й інші риси $[1,4]$. Осмислення з таких позицій творчості вченого-педагога може дати якісно нові пояснення його наукових рефлексій, ідей, поглядів.

Має місце спрощений підхід біографів до осмислення етапів формування та мотивів, стимулів діяльності педагогічної персоналії. Це проявляється в зосередженні уваги на очевидних змінах, учинках, діях, що спричиняли реальні результати, наслідки тощо. Такий аналіз буде глибшим, змістовнішим, якщо науковець ураховуватиме соціально-психологічні й біологічні чинники впливу на особистість на різних етапах онтогенезу.

Так, відомо, що у віці 11 - 15 років відбувається активна психофізіологічна, зокрема ендокринна, статева перебудова організму підлітка, що поряд із соціально-виховними чинниками зумовлюють кристалізацію характеру, особливу поведінкову реакцію, підвищену емоційніть, збудженість тощо. Нерідко ці психологічні стани набувають гіпертрофованих форм i залягають у глибинних пластах підсвідомості, а згодом можуть викликати, здавалося б, немотивовані деформації в характері, неадекватні вчинки, дії тощо [4, 21 - 70, 185 - 237].

Коли біограф шукає мотиви і пояснення вузлової у юнацькому віці дилеми щодо професійного вибору, то має враховувати, що із засвоєнням моральних норм кристалізуються певні життєві стереотипи, які знову ж таки переходять у наступні вікові періоди. На зміну юнацькому максималізму, ідеалізму до 20 - 25річної особи приходять стриманість, врівноваженість, прагматизм, однак зазвичай не відбувається остаточного самовизначення. Саме в цей час багато відомих педагогів кінця XIX - XX ст. розпочинали професійну кар'єру та громадськокультурну працю. Тому при вивченні цього періоду доцільно звертати увагу на те, як, збагачуючись власним досвідом, вони досягали емоційної рівноваги, ставали загартованішими, стійкішими, що, своєю чергою, часто стимулювало інтерес до творчої наукової діяльності. 3'ясовуючи характер творчої, професійної, громадськокультурної діяльності персоналії за наступних життєвих періодів, дослідники, зосереджуючись на творчих здобутках, кар'єрному зростанні, життєвих успіхах і невдачах, пояснюють їх здебільшого зовнішніми, об'єктивними чинниками у вигляді сторонніх ідейних впливів, боротьбою за національні ідеали тощо. При цьому вони зазвичай уникають з'ясування зумовленості цих процесів внутрішніми психофізіологічними змінами, які справляють не менший вплив, аніж перша група чинників.

Попри поширену думку, згідно з якою “кризи дитинства" вивчена гірше, аніж “кризи дорослості", упродовж останніх десятиріч науковці, психологи, геронтологи, представники герменевтики значно просунулися в дослідженні цьогофеномену(В.Алыерович,Р.Ахмеров,В.Гладкова, I. Малкіна-Пих, В. Рижов, Д. Холліс та ін.).

Випрацювана відносно консолідована позиція щодо періодизації цих “життєвих кривих”: “криза 30-річних"; “криза середини життя” (40-45 років); “інволюційна" (50 - 55) і “передпенсійна" (5560) кризи та ін. 3'ясовані загальні особливості, що відрізняють їх від криз дитинства: більший часовий інтервал; менша детермінованість хронологічним віком завдяки нагромадженому життєвому досвіду; істотніша зумовленість 


\section{СТРУКТУРНО-ОСОБИСТІСН АСПЕКТИ ВИВЧЕННЯ ПЕДАГОГІЧНОЇ ПЕРСОНАЛІІ}

фізіологічними змінами (хвороби, гормональний дисбаланс) і зовнішніми умовами (соціальноекономічне середовище, дисбаланс вимог i очікувань) тощо [2].

Поряд із означеними аспектами, при вивченні педагогічної персоналії біограф має усвідомлювати особливості проявів кожної вікової кризи, які позначаються на суспільній діяльності. Творчі особистості гостро переживають "кризу середини життя” через загострення почуття незадоволеності досягнутим, нав'язливу потребу в постійному самоаналізі, картання за дошкульні помилки, недостатню активність, нереалізовані творчі й кар'єрні плани і т. ін. Інволюційний вік часто супроводжується депресивними станами через зниження життєвого тонусу, маніакальне побоювання змін у стилі життя, звуження кола інтересів, згасання когнітивних здібностей, постійне апелювання до минулого тощо.

Водночас важливо розуміти: кожна нормативна вікова криза - це не тільки негативна дезінтеграція, яка супроводжується нарощуванням ознак дезадаптації, а й позитивна, що продукує механізми змін і переходу на новий вищий рівень цілісності. У другому випадку вольовий інтелектуал, долаючи суперечності між “бажаним і досягнутим”, змінює життєву стратегію, будує нові цілі й перспективи, активізує пошук шляхів і засобів їхньої реалізації. Біографії педагогічних персоналій дають безліч таких прикладів, тож дослідник має виявити і пояснити означені й інші психічні стани, що дає ефективний інструмент для глибокого розуміння і комплексної характеристики їхніх творчих і професійних здобутків та невдач.

Отже, стрижень персонологічного структурного аналізу педагогічної персоналії як творчої особистості становить ідея, згідно з якою онтогенетичний розвиток супроводжується і проявляється у своєрідній динаміці різних людських типів та інтегрується в єдності біологічних і соціально-типових тенденцій. Біограф має розуміти, що між типами вищої нервової діяльності, з одного боку, та характером, творчим потенціалом особистості, 3 іншого, існує безсумнівний і виразний взаємозв'язок, який потрібно виявити та пояснити, зокрема крізь призму його впливу на зміст і результат теоретичних пошукувань, професійно-освітніх, науково-організаційних, інших виявів суспільної активності.

Використання науково-теоретичних конструктів персонології може бути особливо продуктивним при вивченні життєдіяльності педагогів за складних і суперечливих періодів історії України (доба сталінського тоталітаризму, “відлиги”, “застою”, “перебудови” тощо), які супроводжувалися втратами в людських долях, суспільними кризами, деформаціями в гуманітарних науках тощо. Усе це зумовлювало відповідні психічні стани в носіїв української педагогічної думки, позначалося на іiї поступі та духовності й ментальності всієї української спільноти.

Треба визнати, що в сучасній український педагогічній біографістиці психосоціальні характеристики персоналій здебільшого представлені доволі фрагментарно, шаблонно, подекуди спрощено, примітивно. Причини такого становища зумовлені не стільки браком джерел, скільки нерозумінням підходів до здійснення комплексного структурного аналізу, відсутністю спеціальних фахових знань, зокрема й через брак відповідних науково-методичних розробок.

Висновки та перспективи подальших досліджень. Отже, з позицій персонології особистість розглядається як організована сукупність властивостей психіки та цілісна окремо взята особа із властивими їй біосоціально зумовленими психологічними характеристиками, зокрема інтересами, потребами, темпераментом, характером тощо. Вона осмислюється крізь призму взаємин з іншими індивідами та як суб'єкт впливу різних чинників, що постійно змінюється (в окремих властивостях і загалом) залежно від умов індивідуального розвитку, соціокультурного середовища, виховання, сімейних стосунків, захворювань тощо. Чимало продуктивних для розвитку досліджень у галузі педагогічної біографістики ідей і концептів висунули представники такого напряму персонології, як гуманістична психологія. Зосередившись на осмисленні проблеми розвитку потенціалу особистості, вони обгрунтували постулати про природну самодостатність людини та ії здатність до постійного самовдосконалення). Спершу в такому статусі структурно-особистісні аспекти вивчення педагогічної персоналії можуть знайти своє особливе місце у вимірі історико-педагогічної науки, а в перспективі - і в структурі всієі педагогічної науки.

\section{ЛІТЕРАТУРА}

1. Айзенк Г., Вильсон Г. Как измерить личность / пер. с англ. А. Белопольського. Москва: Когито-Центр, 2000. 281 с.

2. Гладкова В. М., Пожарський С. Д. Основи акмеології: підручник. Львів: Новий Світ, 2011. 320 с.

3. Погорельцева Ю. А. Психология личности: учебное пособие. Санкт-Петербург: СПб ГТУРП, 2011. 105 c. 
4. Поліщук В. М. Вікова і педагогічна психологія : навчальний посібник. Суми: Університетська книга, 2010. 352 с.

5. Рубинштейн С. Л. Основы общей психологи. Санкт-Петербург: Питер, 2000. 488 с.

\section{REFERENCES}

1. Eysenck, G. \& Wilson, G. (2000). Kak izmerit lichnost [How to measure personality]. trans. with English. A. Belopolsky. Moscow, p. 281. [in Russian].

2. Gladkova, V. M. \& Pozharsky, S. D. (2001).
Osnovy akmeolohii: pidruchnyk [Fundamentals of acmeology]. Lviv, p. 320. [in Ukrainian].

3. Pogoreltseva, Yu. A. (2011). Psikholohiia lichnosti: uchebnoe posobie [Psychology of personality]. St. Petersburg, p. 105. [in Russian].

4. Polishchuk, V. M. (2010). Vikova i pedahohichna psykholohiia [Age and pedagogical psychology]. Sumy, p. 352. [in Ukrainian].

5. Rubinstein, S. L. (2000). Osnovy obshchei psikholohii [Fundamentals of general psychology]. St. Petersburg, p. 488. [in Russian].

Стаття надійшла до редакції 10.01.2020

УДК 378.016:811.161.2’35]:37.015.31:159.955-028.43

DOI:

Валентина Вітюк, кандидат педагогічних наук, доиент кафедри теорії і методики початкової освіти Східноєвропейського національного університету імені Лесі Украӥнки

\section{ЗАСТОСУВАННЯ МЕТОДИЧНИХ ПРИЙОМІВ РОЗВИТКУ КРИТИЧНОГО МИСЛЕННЯ СТУДЕНТІВ ПІД ЧАС ВИВЧЕННЯ ПРАВОПИСУ УКРАЇНСЬКОЇ МОВИ}

У статті окреслено актуальність мовно-мовленнєвої підготовки студентів на сучасному етапі модернізації вищяої освіти в Україні. Зазначено, щчо одним із перспективних напрямів підвищення правописноі грамотності студентів є застосування методичних прийомів розвитку критичного мислення, які забезпечують пізнавальну активність і самостійність мислення, здатність критично оцінити інформацію $і$ сформувати власну стратегію й тактику вирішення конкретного питання для самоствердження й самореалізації особистості в майбутній професійній діяльності. У науково-методичній розвідці описано методичні прийоми: “Бортовий журнал”, “Кластер”, “РОФТ”, читання з маркуванням тексту “INSERT”, “Навчаючи - вчуся”, - визначено їх мету й алгоритм проведення, передбачено очікувані результати роботи, проілюстровано на прикладах нової редакиії “Украӥнського правопису”.

Ключові слова: правопис; критичне мислення; кластер; РОФT; INSERT.

Табл. 3. Схема 1. Лім. 9.

Valentyna Vityuk, Ph.D.(Pedagogy), Associate Professor of the Theory and Methods of Elementary Education Department Lesya Ukrayinka Eastern European National University

\section{THE USE OF TEACHING METHODS FOR THE DEVELOPMENT OF CRITICAL THINKING OF STUDENTS IN THE STUDY OF THE SPELLING OF THE UKRAINIAN LANGUAGE}

The author of the article emphasizes the importance of quality training for students of higher education institutions in the context of modernizing the content of education in Ukraine. The expressed position of the author is confirmed by a certain list of "Skills of the XXI century", in which critical thinking takes the fourth position.

The article is outlined the relevance of cultural and speech training of students at the current stage of reforming higher education in Ukraine. It is noted that one of the promising areas of increasing the literacy of students is the use of methods and techniques for the development of critical thinking, which provide cognitive activity, independent thinking, the ability to critically evaluate an information and formulate your own strategy and tactics for solving a specific issue for self-affirmation and self-realization of a person in future professional activities.

Methodical methods for the development of critical thinking are described that can be used in the study of spelling in the course "Modern Ukrainian language with a practical work". The author of the article suggests the use of "Flight Log", "Cluster", "ROFT", reading with the marking of the text "INSERT", "Teaching Learning” and others. In scientific and methodological intelligence, goals and an algorithm for conducting methodological methods are defined, and expected results of work are provided. The introduction of teaching methods is illustrated by the examples of the new edition of Ukrainian Spelling (2019). The scientific intelligence indicated that for decades leading scientists have focused on the problem of increasing the spelling and punctuation literacy of students of pedagogical universities, since it is communicatively advisable to use the means of language in all types of speech 